\title{
Pathways to Motivate Reluctant Readers: Exploring Teachers' Perception of Using Children's Picture Books to Increase English Language Learners' Reading Motivation
}

\author{
Al Tiyb Al Khaiyali \\ Department of Teaching \& Learning, Washington State University at Pullman \\ 1630 NE Valley Rd Apt V302, Washington, 99163 USA \\ E-mail: aalkhaiyali@wsu.edu
}

Received: 05-01-2014

doi:10.7575/aiac.ijalel.v.3n.3p.130
Accepted: 05-02-2014

Published: 01-05-2014

URL: http://dx.doi.org/10.7575/aiac.ijalel.v.3n.3p.130

\begin{abstract}
Reluctant reading, aliteracy, and readicide are issues that were recently developed as a result of the remarkable decline of learners' reading motivation. One of the major causes of these vexing issues was the paucity of materials that could be implemented to increase learners' reading motivation. To fill this gap, the current study explored teachers' experiences of using children's picture books to increase students' reading motivation. Two English as a second language teachers from the fifth and sixth grades participated in this study. Classrooms were observed and both teachers were interviewed at the end of the fieldwork of this study. Findings from classroom observation notes indicated that teachers spent 462 minutes in delivering reading instructions, tasks, and activities. In the same vein, students spent 329 minutes in reading practices throughout the assigned reading sessions. Finally, both teachers affirmed an increasing interest of reading practices in the participating classrooms comparing to previous reading-periods.
\end{abstract}

Keywords: reading, motivation, picture books, explicit instruction

\section{Introduction}

Reading is considered an essential goal for the success of any literacy and learning program (Hallman, 2009). This is because through various types of reading, students achieve various types of knowledge and accomplish general learning goals (Wigfield \& Guthrie, 1997). Despite its numerous benefits, it was reported that many learners, particularly in ESL and EFL classrooms spend relatively little time on reading (Lee, 2013). This potential problem was primarily due to the lack of readers' motivation and the scarcity of quality materials that were used to teach reading (Earl \& Maynard, 2006; Guthrie \& Davis, 2003). Therefore, the purpose of this study was to explore the use of children's picture books to motivate English language learners to reading. More specifically, the study was informed by the following research questions:

1. To what extent elementary ESL teachers used children's picture books to motivate their students to read?

2. What was the teachers' general experience of using children's picture book to motivate ESL elementary students to read?

\section{Review of literature}

\subsection{Variations among readers' deficiencies}

Throughout research, readers who were not able to read or who lacked reading motivation were grouped into three categories: (1) reluctant readers, (2) aliterate readers, and (3) struggling readers. Johns and Lenski (2001) defined reluctant readers as those who have the ability to read but are not reading frequently. Harris and Hodges (1995) proposed a more broad definition for reluctant readers when they put it, "they may not have the ability or skills to read or may have the skills but, for a variety of reasons, not choose to read" (p.218). The second portion of Harris and Hodges's definition was used by most researchers to define aliterate readers. For example, Beers (1996) and Mikulecky (1978) defined aliterate readers as readers who are able to read but unwilling to do so. On the other hand, struggling readers were defined as readers who encounter difficulties in the reading process. Struggling readers often times require appropriate skills for word recognition, decoding skills, and fluency to master their reading process (Vacca \& Vacca, 1999). Guthrie and Davis (2003) described struggling readers as those who are demotivated, disengaged, and lack selfefficacy. Despite the variations among readers' categories, there was a consensus among researchers that reluctant, aliterate, or struggling readers often overlap and meet in the same line. In other words, most readers who have problems in reading or who lack the interest in reading share common attributes and such attributes contribute significantly to their problems in reading (Manuel \& Brindley, 2012). Additionally, a great deal of researchers reported that readers whether they are reluctant, struggling, or aliterate are usually not doing well in school and are often underachievers (Biancarosa \& Snow, 2004). Recently, Gallagher (2009) coined Readicide to explain the role of institutions in fostering learners' demonization of reading. According to Gallagher, schools and other educational institutions contributed in 
various ways to killing readers' love of reading by providing instructions and pedagogical tools that are not supporting reading motivation.

\subsection{Factors influence reluctant readers}

Understanding the primary causes of learners' reading deficiency and lack of reading interest was considered fundamental in developing methods and approaches to foster reading interest and the ability to read (Brozo \& Flynt, 2008; Sanacore, 2008). Therefore, a considerable numbers of researchers in the fields of reading and literacy unearthed some factors that led to reading reluctance and aliteracy. These factors included: (a) lack of motivation, (b) lack of good and appropriate materials (c) scarcity of background knowledge and previous failures in reading, (d) problems in reading instruction, (e) lack of safe and active environment for reading development (Baker \& Wigfield, 1999; Protacio, 2012).

\subsubsection{Lack of motivation}

According to Guthrie and Wigfield (2000), motivation in reading is "the individual's personal goals, values, and beliefs with regard to the topics, processes, and outcomes of reading" (p. 405).Guthrie and Wigfield pointed out that active and long-term readers are those who are intrinsically motivated. Specifically, intrinsically motivated readers are those who read for pleasure, excitement, and interest. Intrinsically motivated learners usually read because they love reading, spend more time in reading, and show more interests in understanding what they read (Kamil, Manning, \& Walberg, 2002). It was also indicated that motivation whether it is intrinsic or extrinsic is an essential prerequisite for developing learners' interest and love of reading (Higgins et al., 1995; Watkins \& Coffey, 2004; Wigfield et al., 2006). This assumption was supported by a considerable numbers of researchers (Baker \& Wigfield, 1999; Schaffner \& Schiefele, 2007). Additionally, many research studies found that students' lack of motivation was the major indicator of their reading reluctant and students who are motivated to read spend more time on reading than their demotivated peers (Morgan \& Fuchs, 2007; Wigfield \& Guthrie, 1997). For example, Gottfried, Fleming, and Gottfried (2001) examined the long-term impact of students' intrinsic motivation on general academic achievements with a focus on reading. Using a longitudinal study, students were tracked from the middle elementary to the high school years. Results showed that the relationship between readers' intrinsic motivation and reading achievements was strongly correlated.

\subsubsection{Scarcity of background knowledge and past failures in reading}

Several research studies reported that reluctant reading is fueled by learners' past failing experiences and lack of prior knowledge (Measley, 1990). Readers who experience frequent errors and barriers in reading are often apt to continuing failures, hence stop and avoid reading habits (Duffy, 2009). On the other hand, learners' background knowledge or schema was considered an essential indicator to accelerate the reading and comprehension abilities (Alderson, 2000; Anderson \& Pearson, 1988; Chen \& Donin, 1997). Thus, the more background knowledge readers have about the reading topic, the higher interest they could show in reading that topic (Anderson and Pearson, 1988).

\subsubsection{Problems in reading instruction}

In numerous classrooms, particularly language learning settings, learners lack their reading interest because of the reading quality instruction they receive. Many teachers do not focus on building students' reading abilities, basic mechanics of reading, and reading interest and motivation when they teach reading (Lesaux, 2012). Therefore, the lack of quality reading instruction contributed significantly to the increasing decline of the students' interests in reading (Fredericks, 1998).

\subsubsection{Lack of active environment for reading development}

Students' surrounding environment was considered fundamental to their cognitive and reading development. The lack of rich and active learning environment whether in school or at home was correlated directly to language, reading, and the overall academic problems, particularly in minority and language learning classrooms (Krashen, 2004; Molfese, Modglin, \& Molfese, 2003).

\subsubsection{Lack of proper materials}

There was an evidence that reading materials play an essential role in determining the volume of readers' interest and motivation toward reading (McQuillan \& Au, 2001; Worthy, Moorman, \& Turner, 1999). For example, many research studies found that readers' increasing access to various reading materials contributed positively to increasing their reading independence, motivation, interest, and engagement (Halle, Kurtz-Costes, \& Mahony, 1997; McQuillan \& Au, 2001; Wigfield et al., 2006). Nonetheless, despite the important role of material quality in accelerating readers' interest and motivation to read, there was no consensus among researchers of what type of materials could best fulfill the learners' interest in reading, particularly in English language learning settings (Karlin, 1973; Lenski \& Lewis, 2008). To bridge this gap, this study was designed to explore the perceptions and experiences of English language teachers at elementary levels of using children's picture books to accelerate the learners' ability and interest in reading.

\subsection{Definition of children's picture books}

Children's picture books were considered a genre of children's literature through which the story is told by illustrations or short texts and illustrations (Overturf, Montgomery, \& Smith, 2013). According to Culham and Coutu (2008) picture books were defined as the meaningful integration of words, illustrations, and design. In children's picture books, words and illustrations usually complete each other and the meaning of the story can be understood by readers when looking at the illustrations, reading the words, or looking at the illustrations and reading the words at the same time (Jalongo, 
2004). Mitchell (2002) bounded most picture books' features and definitions in her explanation of the meaning of picture books.

She stated:

"picture books" evokes images of brightly colored, beautifully illustrated books that beg to be read. No matter what our age, most of us still enjoy reading them because of their vibrant pictures, rich and evocative language, and poignant and meaningful themes. Picture books speak to us in the same way photographs do. They touch our emotions, delight our senses, appeal to our whimsy, and bring back memories of our childhood. Picture books invite us to curl up and read them. (p. 71)

Lado (2012) added more elements to the characteristics of picture books. These elements included aesthetic (beautifully and artistically designed), easy-to-read, flexible (they cover various topics using various styles simple, complicated, rhymed, and wordless), and thematic materials that could be used to teach different pieces of information. Additionally, Culham (2001) described picture books as "short on pages, but long in meaning” (p. 2).

\subsection{Rationale of using children's picture books to accelerate English language learners' reading motivation}

Picture books found their place in many ESL and EFL classrooms because of their various features and educational power (Early, 1991; Kooy, \& Chiu, 1998). Picture books were described as authentic, easy-reading, contain high frequency words, cover various types of topics, and interesting (Lado, 2012; Stewart, 2002). These features contributed to the success of picture books in teaching various language skills and strategies including writing, critical reading, speaking, and listening (Heitman, 2005; Manarino-Leggett, 1995; Spencer \& Slocum, 2010; Spooner \& Woodcock, 2010). Additionally, picture books were important resources to supplement various content area topics (Fresch \& Harkins, 2009). Children's picture books could be valuable resources to initiate love of reading to English language learners because of their rich illustrations, interesting topics, and high frequency words. These attributes could help English language learners understand the general meaning of the story and some new words even if they do not know their meaning and hence become more motivated and eager to read them. Additionally, being short means offering multiple opportunities to slower and hesitant readers to read the same story over and over and hence indulge more in reading practices. These powerful features and uses of picture books could make these materials good resources to teach and motivate learners' reading abilities, particularly in English language learning classrooms.

\section{Theoretical framework}

This study was essentially informed by some major motivation theories. For example, self-efficacy theory helps to determine the students' overall beliefs about their reading ability (Nicholls, 1990). In this study, it was assumed that the multiple uses of children's picture books could engage the students in reading, make students more efficacious in reading, and thus, increase their reading competency (Schunk \& Zimmerman, 1997). The second rationale of using motivation theories as fundamental theoretical grounds of this study was that picture books were considered authentic and interesting materials. These two important features could lead the participating students to read for joy, and hence, foster their intrinsic motivation of reading (Guthrie \& Wigfield, 2000). Finally, the use of children's picture books was assumed to foster the social aspects of motivation which advocated that engaging readers in social and reciprocal reading tasks contribute to their reading avidity (Wentzel, 1996).

\section{Method}

This study was based on exploratory-based methodology. In qualitative research, exploratory designs are usually used whenever little is known about the phenomenon under investigation (Given, 2008). Previous research indicated that there was a general decline in the overall learners' reading interests (Earl \& Maynard, 2006). In addition, previous research indicated that the lack of readers' background knowledge, insufficient reading instruction, demotivating reading environment, and the paucity of reading materials that could lead to motivating reading instruction were the major factors of students' reluctance in reading (Guthrie \& Wigfield, 2000; Modglin, \& Molfese, 2003; Schaffner \& Schiefele, 2007; Wigfield et al., 2006). Therefore, this study was designed to explore the teachers' perceptions of using some authentic and interesting materials (children's picture books) to increase the students' interest and motivation of reading. An important rationale of using exploratory qualitative design in this study was to provide authentic and naturalistic explanation of the use of children's picture books to foster English language learners' interest and motivation in reading (Maxwell, 2013).

\subsection{Research sites and participants}

This study took place in an ESL school in Denver, Colorado, USA. Two ESL classrooms from the fifth and sixth grades were involved in this study. The rationale of selecting only two classrooms was that these classrooms were the only classes that approved the participation request in the time of the fieldwork of the study. Each classroom contained 25 students. The fifth-grade classroom has 18 females and 7 males while the sixth-grade classroom has 16 females and 9 males. The students' ages are ranged from 12 to 14 years-old. The overall English and reading levels of the participating students was considered pre-intermediate. On the other hand, two English language teachers (a female and a male) participated in this study. The participating teachers' age was ranged from 31 to 37 . Both participating teachers were completing their TESOL graduate degrees in the University of Colorado at Boulder. Table 1 shows the demographic and the English language teaching background of the participating teachers. 
Table 1. Teachers' Demographic and Teaching Background

\begin{tabular}{|c|c|c|l|l|l|}
\hline $\begin{array}{l}\text { Teacher's } \\
\text { pseudonym }\end{array}$ & Age & $\begin{array}{l}\text { Teaching } \\
\text { grade-s }\end{array}$ & $\begin{array}{l}\text { Teaching } \\
\text { experience }\end{array}$ & Philosophy of teaching reading & $\begin{array}{l}\text { Philosophy of teaching } \\
\text { language }\end{array}$ \\
\hline Malek & 37 & $6^{\text {th }}$ & Eleven years & $\begin{array}{l}\text { Choral reading is important for } \\
\text { beginning readers. Reading is } \\
\text { based on building the } \\
\text { pronunciation skills, vocabulary } \\
\text { knowledge, and repetition. }\end{array}$ & $\begin{array}{l}\text { Language learning is } \\
\text { based on memorizing } \\
\text { new vocabulary, } \\
\text { motivation, and building } \\
\text { safe and interactive } \\
\text { learning environment. }\end{array}$ \\
\hline Sarah & 31 & $5^{\text {th }}$ & Seven years & $\begin{array}{l}\text { Teachers should be the role- } \\
\text { model in reading instruction, } \\
\text { particularly to beginner readers. } \\
\text { Reading should be taught } \\
\text { according to the learner' needs } \\
\text { and the class objectives. }\end{array}$ & $\begin{array}{l}\text { Language learning is } \\
\text { reciprocal. Teachers and } \\
\text { students interchangeably } \\
\text { share the process of } \\
\text { knowledge transfer. }\end{array}$ \\
\hline
\end{tabular}

\subsection{Materials}

Four picture books were selected to be used to lead the instructional practices of this study (two for each grade level). The picture books selection was based on guidelines encouraged by previous research studies (Jalongo, 2004; Lado, 2012). The main guidelines that were used to select picture books for this study were authenticity (they relevant to the students' life and real world), easy-to-read, interesting, short and not time consuming, contain high frequency words, culturally relevant, comprehensible, not stereotypical, and well-illustrated. The four selected picture books were intensively implemented in both participating classrooms. Specifically, each teacher used two picture books in seven English language class periods and encouraged the students to read them at home. This gave all the participating students an opportunity to read and practice reading at home. Table 2 shows the annotated bibliographic details of the details picture books.

Table 2. Annotated Bibliography of the Selected Picture Books

\begin{tabular}{|l|l|l|l|l|l|}
\hline Title & Author & Illustrator & $\begin{array}{l}\text { Year } \\
\text { of } \\
\text { Publi } \\
\text { cation }\end{array}$ & Publishers & Summary \\
\hline $\begin{array}{l}\text { The } \\
\text { Gardener }\end{array}$ & Stewart & Small & 2007 & $\begin{array}{l}\text { Square } \\
\text { Fish, NY }\end{array}$ & $\begin{array}{l}\text { A young girl 'the gardener' tells her life } \\
\text { story using letters she wrote to her family when } \\
\text { she left them and lived away with her uncle. } \\
\text { In this story, the young girl discovered that her } \\
\text { uncle was always sad and introvert. In order to } \\
\text { draw a smile in his face, she prepared a surprise } \\
\text { for him. The young girl invited her uncle to come } \\
\text { upstairs and on the roof of the hose she showed him } \\
\text { a garden she made to please him and all ends } \\
\text { happily. }\end{array}$ \\
\hline $\begin{array}{l}\text { The } \\
\text { Giving } \\
\text { Tree }\end{array}$ & Silverstein & Silverstein & 1964 & $\begin{array}{l}\text { Harper \& } \\
\text { Row, NY }\end{array}$ & $\begin{array}{l}\text { A boy and a tree love each other and they were } \\
\text { very happy. The boy grew up and started } \\
\text { continuously visiting the tree, playing with her, } \\
\text { and showing her his love and both were very } \\
\text { happy. The boy grew older and started asking the } \\
\text { tree to give him money and things that he needed } \\
\text { for his life. The tree gave the boy everything she } \\
\text { has, and both were happy. Finally and at the end of } \\
\text { the story, the tree asked the boy to sit on its trunk } \\
\text { because it has nothing to give. The tree accepted } \\
\text { the boy's request, and it all ended happily. }\end{array}$ \\
\hline $\begin{array}{l}\text { If You } \\
\text { Give } \\
\text { Mouse a } \\
\text { Cookie }\end{array}$ \\
$\begin{array}{l}\text { The Very } \\
\text { Hungry } \\
\text { Caterpillar }\end{array}$
\end{tabular}




\subsection{Teaching procedures}

Both participating teachers were introduced to a three-day (60 minutes per day) professional development and training program. In the training development program, teachers were coached of how to use picture books to inspire the learning of reading. Teachers were also introduced to what picture books they should use, how, and why they use them in their reading programs. The professional development program included also some instructions and tasks encouraged by previous researchers and theorists (Sullo, 2009). For example, many research studies affirmed the use of motivating tasks and creating motivating environment through which reading takes place. In the professional development program, teachers were trained of how to create motivating reading environment using picture books, implement explicit reading instruction, and provide rich explanation of unfamiliar words. Additionally, reading aloud, providing multiple opportunities for students to read, providing constructive feedback, and scaffolding were emphasized.

\subsection{Data collection}

Since the purpose of this qualitative-based inquiry was to obtain an in-depth understanding of improving reading instruction and pedagogical practices using picture books, data were only elicited from the participating teachers. Classroom observations and teachers' semi-structured interviews were implemented as a main means to collect data for this study. Additionally, the researcher's firsthand memo notes were used to enrich the collected data. After completing the professional development program, teachers were given the opportunity to use four picture books for reading instruction in the fifth and sixth grade classrooms. Reading instruction was administrated for seven days. During the reading sessions, both participating teachers and students were observed. The observation notes included reactions, interactions, and the time of reading engagement of the participating classes. Specifically, teachers' time of reading instruction and students' time in reading was reported. At the end of the reading instructional practices, both teachers were interviewed. Teachers were asked about how they experienced the use of children's picture books to motivate and accelerate their students' reading. In order to assure the validity of the obtained data, the interview questions were piloted a year ahead of this study.

\subsection{Data analysis}

Data that were collected from different sources in this study were thoroughly analyzed. The process of data analysis for this study was informed by its research questions and theoretical framework (Creswell, 2007; Glaser \& Strauss, 1967). This helped me obtain an in-depth and clear understanding of the participating teachers' perspectives and experiences of the use of children's picture books to motivate the students' reading abilities. The analysis process began before the fieldwork and continued through the post-fieldwork of this study (Merriam, 2009). In the first analytic step and before I started the fieldwork of this study, I went through the research literature that I used for this study. The purpose of reviewing the previous literature thoroughly was to understand the main reading challenges of various readers and to suggest solutions based upon these challenges. One of the major challenges that were extracted from previous research was the paucity of interesting materials. In the in-field analysis phase, I started recording some notes from the classroom observations. These notes focused on the teachers' instructional practices, the students' reactions toward the use of picture books in their reading practices, and the time spent in reading among students. In this phase, all the collected data was represented, condensed, and coded (Miles, Huberman, \& Saldana, 2014). The third step, however, was the post-field data analysis. In this phase, all the collected data were reviewed, compared against each other, and finally, reported. Through the analysis processes, the three methods of "data condensation", "data display", and "drawing and verifying conclusions" were implemented (Miles, Huberman, \& Saldana, 2014, pp. 12-13) with a major focus on the thematic analysis of data. Finally, ATLAS.ti 7 (Friese, 2012); a software program designed to analyze qualitative data was employed to affirm the coded data and demonstrate the basic findings of this study.

\section{Findings}

The purpose of this study was to explore the experiences of ESL teachers at the fifth and sixth grades of using children's picture books to motivate students' reading abilities. Two teachers participated in this study. Both teachers were involved in professional development program in order to learn about children's picture books, why they were selected to teach reading, how, and when they should be used. Also, both teachers were introduced to explicit reading instruction and how it should be implemented using picture books. After they completed the training program, both teachers started teaching reading using picture books. The teachers focused on involving their students on reading by starting reading one of the selected picture books aloud, explaining it, providing an opportunity for the students to read it silently, and finally, supporting the students by providing constructive scaffold and feedback about the story. Based on the observed practices and activities in both classrooms and the teachers' interview responses, the following themes emerged: (a) teachers' reading instructional time, (b) students' time of reading, (c) attributes of picture books, (d) components of explicit reading instruction, and (e) challenges of reading instruction using picture books.

\subsection{The amount of teachers' reading instruction}

Findings from the classroom observation notes indicated that the participating teachers' in the fifth and sixth grade classrooms found multiple opportunities to practice reading. Teachers in both classrooms were starting each reading class reading the picture book aloud, providing some time to the students to read the picture books silently, and practice shared reading at the end of the class by encouraging the students to read in groups. Despite the fact that there were only 45 minutes allotted to each English class in the assigned fifth and sixth grade classes, teachers found multiple opportunities to engage the students in reading practices and tasks. For example, when introducing The Gardener; Malek, the sixth grade teacher, spent about three minutes in reading the story aloud, seven minutes in explaining the 
new words, and four minutes in explaining the story. The class activities, students' independent silent reading, students' read aloud, and students' shared-reading lasted for about 31 minutes. Table 3 shows an approximate time amount of teachers' reading instruction in the participating classrooms.

Table 3. Reading Instruction Time Amount in Fifth and Sixth Grade Classrooms

\begin{tabular}{|c|c|c|c|c|c|}
\hline Grade & $\begin{array}{l}\text { Total } \\
\text { reading } \\
\text { classes }\end{array}$ & Type of instruction & Time spent & Total time & $\begin{array}{l}\text { Total of } \\
\text { reading time }\end{array}$ \\
\hline \multirow[t]{5}{*}{ Fifth grade } & \multirow[t]{5}{*}{ Seven } & Read aloud & Three minutes & 21 minutes & \multirow[t]{5}{*}{238} \\
\hline & & Vocabulary instruction & Seven minutes & 49 minutes & \\
\hline & & Sustained silent reading & $\begin{array}{l}\text { Seventeen } \\
\text { minutes }\end{array}$ & 119 minutes & \\
\hline & & Story discussion & Four minutes & 28 minutes & \\
\hline & & Shared reading & Fourteen & 98 minutes & \\
\hline \multirow[t]{5}{*}{ Sixth grade } & \multirow[t]{5}{*}{ Seven } & Read aloud & Four minutes & 28 minutes & \multirow[t]{5}{*}{224} \\
\hline & & Vocabulary instruction & Six minutes & 42 minutes & \\
\hline & & Sustained silent reading & Fifteen minutes & 105 minutes & \\
\hline & & Story discussion & Seven minutes & 49 minutes & \\
\hline & & Shared reading & Thirteen minutes & 91 minutes & \\
\hline Total & & & & 630 minutes & 462 minutes \\
\hline
\end{tabular}

As shown in Table 3, both teachers in the fifth and sixth grades spent 462 minutes in seven reading classes to engage their students in various reading practices. These practices included reading aloud, sustained silent reading, and shared reading. This was not the case when both teachers were teaching using the basal reading materials. Sarah, the fifth grade teacher, affirmed this by saying, "We found multiple opportunities to practice various types of reading in one class period". In her interview responses, Sarah mentioned "I found picture books short, interesting, authentic, with highfrequency words, and delightful illustrations that is why they were accepted by most of my students." Sarah's responses showed that some attributes of picture books that had not existed in the previous reading materials the teachers used were fundamental to increase the students' engagement in reading practices. In the same vein, Malek, the sixth grade teacher indicated, "the simplicity and the interestingness" of picture books were the major factors that gave him the opportunities to create safe and motivating reading environment to his students. When both teachers were asked about the differences in reading instruction before they used picture books and while they were using picture books, both teachers affirmed that picture books gave them more space and time to use various reading instructions. For example, Sarah, the fifth grade teacher pointed out, "I was spending half of my reading class explaining the meaning of new words when I used my basal English reading material."

\subsection{Students' time amount of reading}

The main focus of this study was to explore the teachers' perceptions in the fifth and sixth grades of using children's picture books to motivate reluctant reading students. Analyzing and describing the students' experiences were beyond the scope of this study. Nevertheless, as shown in Table 3, the students overall time of reading was remarkable. In both classrooms, the students practiced reading for about 329 minutes.

\subsection{Attributes of picture books}

Both participating teachers indicated that there were some features of picture books that contributed to their overall success in motivating the reading abilities of fifth and sixth grade students. These features were "short", "not time consuming," "interesting," "authentic," "contain highly frequency words," "illustrative," "delightful," "comprehensible," and "easy-to-read". Malek, the sixth grade teacher, pointed out, "being short was an important feature of picture books because it helped me engage my students in long-time reading opportunities." Sarah, the fifth grade teacher, explained, "The illustrations in picture books helped my students understand what is going on in the story, guess the meaning of difficult words, and enjoy reading the story." Figure 1shows the major attributes of picture books as indicated by the participating teachers and filtered by ATLAS.ti7. 


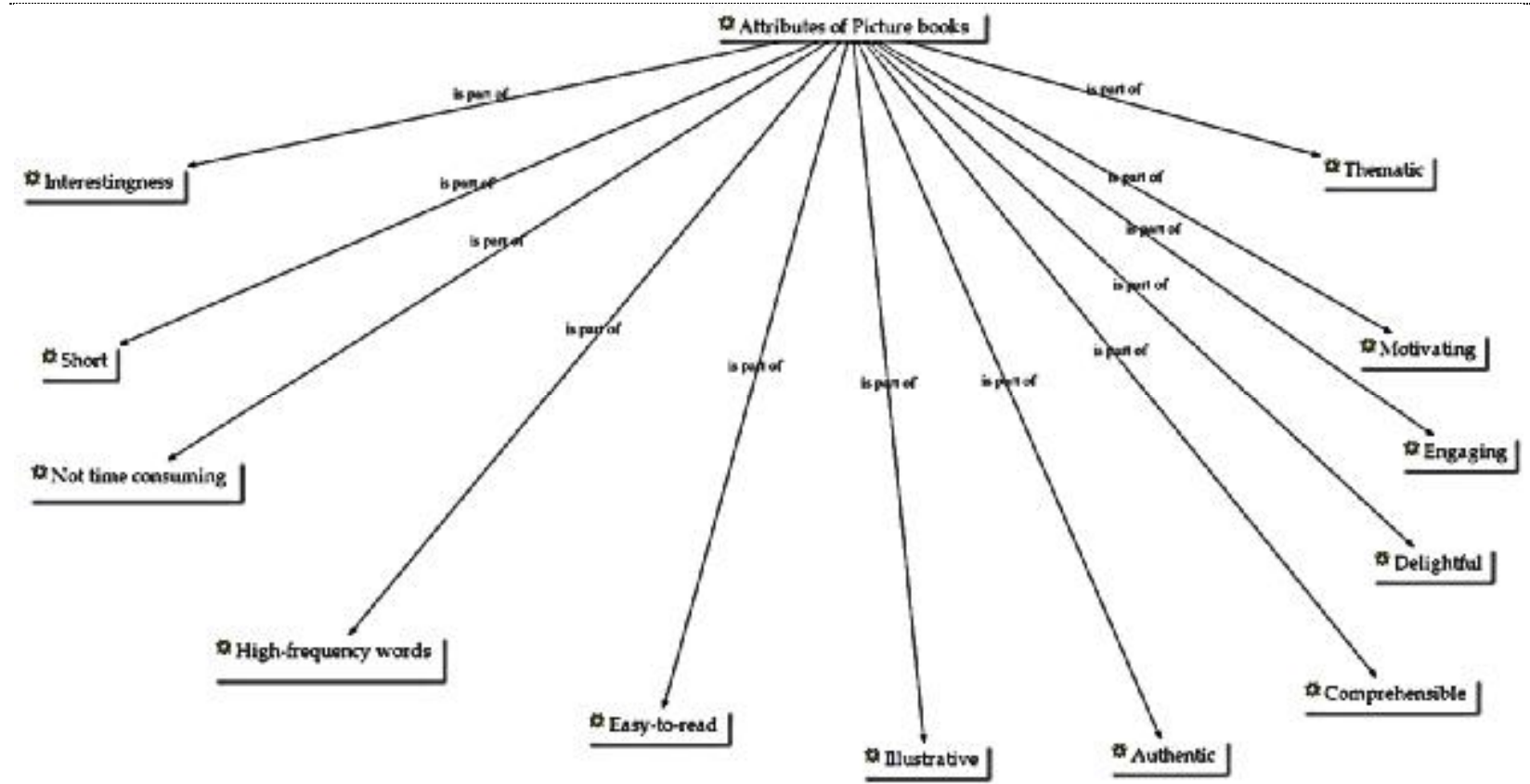

Figure 1. Attributes of children's picture books as filtered by ATLAS.ti7

\subsection{Components of explicit reading instruction}

Both the fifth and sixth grade teachers were involved in three-day professional development program. In this program, the teachers' were trained of how to use picture books to teach and motivate the students to read in the classroom. The tasks, methods, and instructions that were presented in the professional development program were based on approaches and models encouraged by previous research studies. In their teaching program, both teachers affirmed most of the tasks, activities, and instructions that they experienced in the professional development program. Both teachers emphasized that teaching reading and motivating English language learners should involve the explicit instruction of reading practices. Findings from the classroom observation notes and the teachers' interviews indicated that explicit reading instruction should implement modeling through which teachers practice reading by reading the text aloud and using think aloud to describe this process. Additionally, it should involve reciprocal instruction through which teachers and students take mutual roles in the instructional process. Finally, explicit reading instruction should involve teachers' scaffolding and constructive feedback. Figure 2 illustrates the major components of explicit reading instruction as affirmed by both participating teachers.

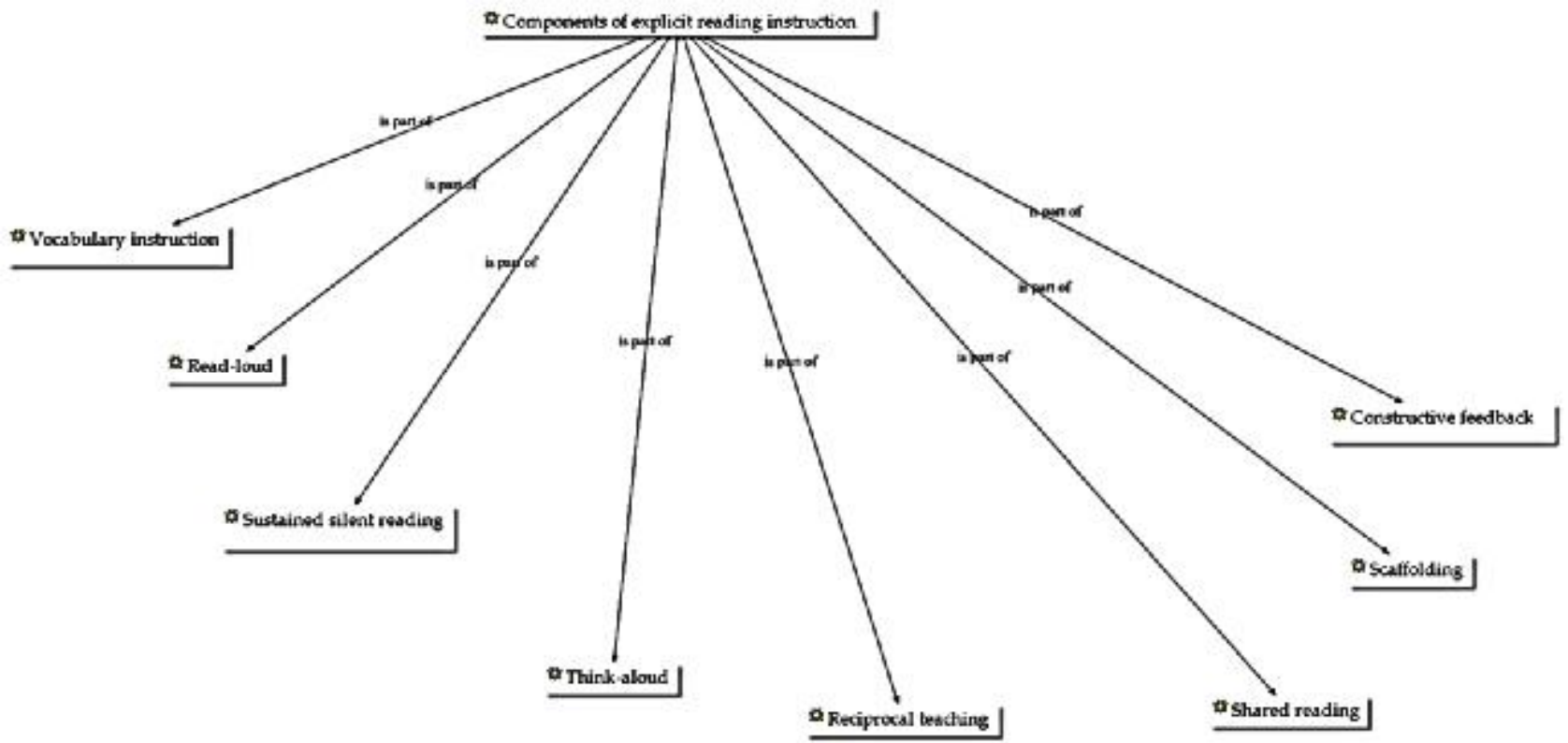

Figure 2. Components of explicit reading instruction

\subsection{Challenges of using picture books in explicit reading instruction}

Despite the positive contribution of picture books in motivating students' reading abilities, some challenges were reported by the participating teachers. Specifically, both teachers indicated that the lack of vocabulary knowledge constituted the major challenge among the fifth and sixth grade students. Many students in the fifth and sixth grades did not know the meaning of some words that were used in picture books. Although illustrations helped them interpret the general meaning of some new words but still they were unable to pronounce them correctly. Both teachers emphasized that the lack of vocabulary knowledge among some students was the major challenge they faced in teaching reading 
using picture books. This was because both teachers took some time explaining the meaning of new words to the students, some time showing the correct pronunciation of the new words while they were listening to the students reading the stories, and some time correcting the students' understanding of the meaning of the new words. Additionally, both teachers affirmed that the large numbers of the students in each class (about 25students per a class) and the shortage of the reading time instruction (only 45 minutes per a class period) were considered other challenges that contributed to some difficulties of reading instruction in the fifth and sixth grade classrooms.

\section{Discussion and implications}

The purpose of this study was to explore the experiences and perceptions of fifth and sixth grade teachers of English as a second language in using children's picture books to motivate their students' reading abilities. Four picture books were selected to be used in two different classrooms (two picture books for each classroom) to teach reading. Two English language teachers were involved in this study. Both teachers were trained to use picture books to motivate and teach reading abilities to their students. After the completion of the professional development program, both teachers started using picture books to teach reading for seven English class periods. The participating classes were observed and both teachers were interviewed at the end of this study. Data were collected from the classroom observations and the teachers' interviews, condensed, displayed, and finally, reported. Findings from the collected data indicated that teachers found more space to engage their students into various reading practices. Specifically, in both classrooms, 462 minutes were devoted to teach and use reading practices differently. This finding was remarkable comparing to the overall amount devoted to reading instruction before this study. Both teachers found that the authenticity in addition to some basic attributes of picture books helped them find multiple ways to motivate and engage students to read. According to both teachers, being short means having more time for all students to read over and over and being interesting means having more opportunities for students to motivate and increase their interest in reading. Findings had also indicated that children's picture books provided a vast space for explicit reading instruction. In this study, both teachers were able to read the assigned picture books aloud, explain the meaning of the unfamiliar words, provide sufficient time for students to read the picture books silently, provide a good amount of time for students to talk about the picture books, and afford sufficient time for students' shared-reading in both classrooms. On the other hand, both teachers affirmed that the number of the students in each class and the shortage of the overall time of reading instruction were the main concerns to teach reading in the participating classrooms. Methodologically speaking, the use of only two major resources to collect data from the participating teachers could not help to triangulate the obtained findings. Additionally, despite the in-depth and richness of the findings of this study, these findings could not be generalizable to other populations because the data were only obtained from two teachers using deductive resources. In spite of these challenges, results from this study could contribute to the following implications: First, the findings of this study will provide English language teachers and researchers general guidelines for the selection and the use of children's picture books to motivate and increase the students' love of reading, particularly at lower grade levels. Second, the findings of this study afford promising indications that picture books could be used to trigger students' intrinsic motivation to read. It was indicated that improving intrinsic motivation could be accomplished under the condition that students read for the purpose of reading. Results from the interview transcripts of the teachers in the fifth and sixth grades and the findings of classroom observation notes affirmed that students spent more time on reading the stories despite the fact that that they were not assessed or rewarded for that. Both teachers emphasized that the students' reading self-efficacy, the students' access to authentic and interesting materials (picture books), the students' access to explicit reading instruction, and the students' autonym and teachers' support, scaffold, and feedback were the major factors of students' motivation to read. Moreover, picture books could afford multiple opportunities for students to select what they like to read since they are numerous and cover wide areas of topics. These important findings were consistent with findings of previous research studies that were conducted in reading and literacy development settings (Guthrie, \& Wigfield, 2000; Wigfield \& Guthrie, 1997). Additionally, it was emphasized by both teachers that a serious of pedagogical and instructional shifts in teachers' education is strongly required in order to transfer readers in language learning contexts from reluctant to inspired. It was not only about teaching students some reading practices, rather, it was mainly about teaching them how to love what they were doing (reading). This essential goal was affirmed by Trelease (1989) when she put it, "teaching children how to read is not enough, we must also teach them to want to read" (p.204). Finally, the findings of this study could enrich the body of research in sustain learners' motivation to read.

\section{Conclusion}

Reading is considered the fundamental key to acquire any new knowledge. It is an essential part in any academic and educational program. Despite these essentials, many students, particularly in English as a second and English as a foreign language are not showing any interests or motivation to read. Many researchers and theorists investigated this vexing issue and found that the lack of background knowledge, rigours reading instruction, and interesting motivating materials were the major causes of this problem. In many ESL and EFL classrooms, teaching reading could be a daunting task because in such classrooms teachers are using only text-basal materials. These materials could be challenging and boring because of their mechanical vocabulary, complicated sentence structure, and uninteresting topics they cover (Downing, 2005; Farrell, 2009). Therefore, this study explored the experiences of fifth and sixth grade teachers of English as a second language in using children's picture books to promote students' reading motivation. Picture books were chosen because they were short, interesting, authentic, and cover various topics. Teachers were involved in three-day professional development program to practice how and when they can use picture books to motivate their students to read. Findings of classroom observations and teachers' interviews indicated that students in both classrooms showed higher motivation in reading. This was extracted from the increasing time that students spent in 
reading. Moreover, teachers provided multiple instructional opportunities for students to reading practices. Despite some concerns that were reported by the participating teachers regarding the students' numbers and shortage of time, this study could contribute to the body of research on developing the motivation of reluctant readers in English language learning classrooms.

\section{References}

Alderson, J. C. (2000). Assessing reading. Cambridge: Cambridge University Press.

Anderson, R. C., \& Pearson, D. P. (1988). 'A schema-theoretic view of basic processes in reading comprehension'. In P. L. Carrell, J. Devine, \& D. E. Eskey (Eds.), Interactive approaches to second language reading (pp. 37-55). Cambridge, England: Cambridge University Press.

Baker, L., \& Wigfield, A. (1999). Dimensions of children's motivation for reading and their relations to reading activity and reading achievement. Reading Research Quarterly, 34, 452-477. doi:10.1598/RRQ.34.4.4

Beers, K. (1996). No time, no interest, no way!: The 3 voices of aliteracy. School Library Journal, 42(2), 30-33.

Biancarosa, G., and Snow, C. (2004). Reading next: A vision for action and research in middle and high school literacy - A report to Carnegie Corporation of New York. Washington, DC: Alliance for Excellent Education.

Brozo, W., \& Flynt, S. (2008). Motivating students to read in the content classroom: Six evidence-based principles. The Reading Teacher, 62 (2), 172-174.

Chen, Q., \& Donin, J. (1997). Discourse processing of first and second language biology texts: Effects of language proficiency and domain-specific knowledge. The Modern Language Journal, 81, 209-227.

Creswell, J. (2007). Qualitative inquiry and research design: Choosing among five approaches (2ed Ed.). Thousand Oaks, CA: Sage Publications, Inc.

Culham, R. (2001). Picture books can help middle schoolers write better. Retrieved January 6th, 2013, from http:/www.nwrel.org/nwreport/aug00/picture.html

Culham, R., \& Coutu, R. (2008). Using picture books to teaching writing with traits. New York: Scholastic, Inc.

Downing, J. (2005). Teaching literacy to students with significant disabilities: Strategies for the K-12 inclusive classroom. Thousand Oaks, CA: Corwin Press.

Duffy, G. (2009). Explaining reading: A resource for teaching concepts, skills, and strategies (2ed Ed.). New York, NY: The Guilford Press.

Earl, A., \& Maynard, S. (2006). What makes a child a reluctant reader? New Review of Children's Literature \& Librarianship, 12 (2), 163-181.

Early, M. (1991). Using wordless picture books to promote second language learning. ELT Journal, 45 (3), $245-251$.

Farrell, T. (2009). Teaching reading to English language learners. Thousand Oaks, CA: Corwin Press.

Fredericks, A. (1998). The integrated curriculum: Books for reluctant readers, grades 2-5 (2ed Ed.). Englewood, CO: Teacher Ideas Press.

Fresch, M. J., \& Harkins, P. (2009). The power of picture books: Using content area literature in middle school. Urbana, Ill: National Council of Teachers of English.

Friese, S. (2012). Qualitative data analysis with ATLAS.ti. London, UK: SAGE.

Given, L. (Ed.). (2008). The SAGE encyclopedia of qualitative research methods (V II.). Thousand Oaks, CA: SAGE Publications, Inc.

Glaser, B., \& Strauss, A. (1967). The discovery of grounded theory: Strategies for qualitative research. Chicago, IL: Aldine, Co.

Gottfried, A., Fleming, J., \& Gottfried, A. (2001). Continuity of academic intrinsic motivation from childhood through late adolescence: A longitudinal study. Journal of Educational Psychology, 93 (1), 3-13.

Guthrie, J., \& Davis, M. (2003). Motivating struggling readers in middle school through an engagement model of classroom practice. Reading \& Writing Quarterly, 19 (1), 59-85.

Guthrie, J., \& Wigfield, A. (2000). 'Engagement and motivation in reading'. In M. L. Kamil, P. B. Mosenthal, P. D. Pearson, \& R. Barr (Eds.). Reading research handbook (Vol. 3, pp. 403-422). Mahwah, NJ: Erlbaum.

Halle, T., Kurtz-Costes, B., \& Mahony, J. (1997). Family influences on school achievement in low-income, African American children. Journal of Educational Psychology, 89, 527-537.

Hallman, J. (2009). 'Reading aloud: Comprehending, not word calling'. In R. Stone. (Ed.). (2009). Best practices for teaching reading: What award-winning classroom teachers do. Thousand Oaks, CA: A SAGE Company.

Harris, T. L., \& Hodges, R.E. (Eds.). (1995). The literacy dictionary: The vocabulary of reading and writing. Newark, DE: International Reading Association.

Heitman, J. (2005). Picture this: Using picture books to teach writing skills. Library Media Connection, 23(7), 36-38.

Higgins, T., Lee, J., Kwon, J., \& Trope, Y. (1995). When combining intrinsic motivations undermines interest: A test of activity engagement theory. Journal of Personality and Social Psychology, 68 (5), 749-767. 
Jalongo, M. (2004). Young children and picture books (2ed Ed.). Washington, DC: National Association for the Education of Young Children.

Johns, J., \& Lenski, S. (2001). Improving reading strategies and resources ( $3^{\text {rd }}$ Ed.). Dubuque, IA: Kendal/Hunt Publishing Company.

Kamil, M., Manning, J., \& Walberg, H. (Eds.). (2002). Successful reading instruction. Greenwich, Conn: Information Age Publishing.

Karlin, R. (Ed.). (1973). Perspectives on elementary reading: Principles and strategies of teaching. San Diego, CA: Harcourt Brace Jovanovich, Inc.

Kooy, M., \& Chiu, A. (1998). Language, literature and learning in the ESL classroom. English Journal, 88(2), 78-84.

Krashen, S. (2004). The power of reading: Insights from the research. Portsmouth, NH: Heinemann.

Lado, A. (2012). Teaching beginner ELLs using picture books: Tellability. Thousand Oaks, CA: CROWIN SAGE.

Lee, H. (2013). An examination of ESL Taiwanese university students' multimodal reading responses. Literacy Research \& Instruction, 52, 192-302.

Lenski, S., \& Lewis, J. (Eds.). (2008). Reading success for struggling adolescent learners. New York, NY: The Guilford Press.

Lesaux, N. (2012). Reading and reading instruction for children from low-income and non-English- speaking households. The Future Children, 22 (2), 73-88.

Manarino-Leggett, P. (1995). Children's literature: A springboard to literacy. Reading Improvement, 32 (1), 42-45.

Manuel, J., \& Brindley, S. (2012). Teenagers and reading: Literary heritages, cultural contexts, and contemporary reading practices. Kent Town, Australia: Wakefield Press.

Maxwell, J. (2013). Qualitative research design: An interactive approach ( ${ }^{\text {rd }}$ Ed.). Thousand Oaks, CA: SAGE Publications, Inc.

McQuillan, J., \& Au, J. (2001). The effect of print access on reading frequency. Reading Psychology, 22, (225-248).

Measley, D. (1990). Understanding the motivation problems of at-risk college students. Journal of Reading, 33, 598601.

Merriam. S. (2009). Qualitative research: A guide to design and implementation. San Francisco, CA: John Wiley \& Sons, Inc.

Mikulecky, L. (1978, May). Aliteracy and a changing view of reading goals. Paper presented at the annual meeting of the International Reading Association, Houston, TX. (ERIC Document Reproduction Service No. ED 157 052)

Miles, M., Huberman, M., \& Saldana, J. (2014). Qualitative Data Analysis: A Methods Sourcebook ( ${ }^{\text {rd }}$ Ed.).Thousand Oaks, CA: SAGE Publications, Inc.

Mitchell, D. (2002). Children's literature: An invitation to the world. Boston: Allyn \& Bacon.

Molfese, V., Modglin, A., \& Molfese, D. (2003). The Role of Environment in the Development of Reading Skills: A Longitudinal Study of Preschool and School-Age Measures. Journal of Learning Disabilities, 36 (1), 59-67.

Morgan, P.L., \& Fuchs, D. (2007). Is there a bidirectional relationship between children's reading skills and reading motivation?. Exceptional Children, 73 (2), 165-83.

Nicholls, J. (1990). What is ability and why are we mindful of it? A developmental perspective. In R. Sternberg \& J. Kolligian (Eds.), Competence considered (pp. 11-40). New Haven, CT: Yale University Press.

Overturf, B., Montgomery, L., \& Smith, M. (2013). Word nerds: Teaching all students to learn and love vocabulary. Portland, ME: Stenhouse Publishers.

Protacio, M. (2012). Reading motivation: A focus on English learners. The Reading Teacher, (1), 69-77.

Sanacore, J. (2008). Turning reluctant learners into inspired learners. The Clearing House: A Journal of Educational Strategies, 82 (1), 40-44.

Schaffner, E., \& Schiefele, U. (2007). Auswirkungen habitueller Lesemotivation auf die situative Textrepra"sentation [Effects of habitual reading motivation on the situative representation of text]. Psychologie in Erziehung und Unterricht, 54, 268-286.

Schunk, D. H., \& B. J. Zimmerman. (1997). 'Developing self-efficacious readers and writers: The role of social and self-regulatory processes'. In Reading engagement: Motivating readers through integrated instruction, 34-50., ed. J. T. Guthrie and A. Wigfield. Newark, DE: International Reading Association.

Spencer, T., \& Slocum, T. (2010). The effect of a narrative intervention on story retelling and personal story generation skills of preschoolers with risk factors and narrative delays. Journal of Early Intervention, 32(3), 178-199.

Spooner, L., \& Woodcock, J. (2010). Teaching children to listen: A practical approach to developing listening skills. New York, NY: Continuum International Publishing Group.

Stewart, M.P. (2002). Judging authors by the color of their skin? Quality Native American children's literature. MELUS, 27(1), 179-96. 
Sullo, B. (2009). The motivated student: Unlocking the enthusiasm for learning. Alexandria, VA: Association for Supervision and Curriculum Development.

Trelease, J. (1989). The new read aloud handbook. New York: Penguin Books.

Watkins, M., \& Coffey, D. (2004). Reading motivation: Multidimensional and indeterminate. Journal of Educational Psychology, 96(1), 110-118.

Vacca, T., \& Vacca, J. (1999). Content area reading. New York, NY: Longman.

Wigfield, A., Eccles, J. S., Schiefele, U., Roeser, R. W., \& Davis-Kean, P. (2006). 'Development of achievement motivation'. In W. Damon \& N. Eisenberg (Eds.), Handbook of child psychology (6th ed., pp. 933-1002). New York, NY: Wiley.

Wentzel, K. R. (1996). Social and academic motivation in middle school: Concurrent and long-term relations to academic effort. Early Adolesc, 16, 390-406.

Wigfield, A., \& Guthrie, J. (1997). Relations of children's motivation for reading to the amount and breadth of their reading. Journal of Educational Psychology, 89 (3), 420-432.

Worthy, J., Moorman, M., \& Turner, M. (1999). What Johnny likes to read is hard to find in school. Reading Research Quarterly, 34, 12-27. 